\title{
Educating Our Patrons: Teaching with Primary Sources in Educational Outreach in Medical Archives
}

\section{By Elizabeth Shepard}

ABSTRACT: For the past two decades, the wider archives community has embraced the growing trend of using primary sources in both informal and formal educational outreach activities to both engage audiences and teach students critical thinking skills. The author conducted a study using a survey consisting of 36 questions and follow-up interviews to investigate how medical archivists and special collections librarians in medical archives are embracing this trend of using primary sources in educational outreach. The results indicate that medical archivists/librarians are using primary sources in a variety of traditional educational outreach activities such as exhibits, archives tours, and archival orientation sessions to educate and engage audiences on a variety of subjects, including the history of medicine and health sciences, science, art, and literature. However, only a few medical archivists/librarians reported that they are engaged as co-teachers or solo teachers of credited courses. There are many challenges to providing opportunities for medical archivists/librarians to participate in formal educational outreach, including integrating the archives in the parent organization's educational curriculum, lack of human resources, and lack of visibility of the archives. Despite these hurdles, medical archivists and special collections librarians need to think more creatively about how their collections can be used to educate audiences and other ways they can participate more fully in this important educational opportunity.

\section{Introduction}

Over the past two decades, the wider archival community has embraced the trend of using primary sources to educate users in both informal and formal educational outreach activities. Archivists use primary sources to engage audiences in a variety of traditional educational outreach activities such as exhibits, archival tours, and archival orientation sessions. In these types of activities, archivists employ primary sources to engage their audiences and educate them about the archives, collections, or specific topics. Here, the emphasis is on making history come alive to users by telling a narrative story through selected primary sources. In recent years, educational reformers from primary to higher education have promoted inquiry-based learning pedagogies to educate students. An integral part of this movement is using primary sources to help students at all levels develop critical thinking skills. Academic archivists have risen to the opportunity to not only provide primary source materials to faculty and teachers, but to become educators themselves by engaging in formal education activities at their institutions by offering faculty consultations and independent archival orientation sessions, and teaching or co-teaching curriculum-based courses. 
The author conducted a study using a survey and follow-up interviews to examine how the medical archives community has responded to this trend. The results of the study indicate that most medical archives engage in traditional forms of educational outreach. The majority of the 22 respondents who reported doing so are educating students in traditional formats such as archival orientations and independent studies. However, only a small number of medical archivists/librarians reported that they co-teach or solo teach credited courses. Some of the challenges in providing formal educational outreach activities to students include integrating the archives with the parent organization's educational curriculum, a lack of human resources, and a lack of visibility of the archives. Nevertheless, medical archivists/librarians employ primary sources in both informal and formal educational settings to both engage and educate their audiences.

\section{Teaching with Primary Sources Trend in K-12 and Higher Education}

The trend is growing in both $\mathrm{K}-12$ and higher education classrooms to use primary sources to educate students and help them to develop critical thinking skills. Both $\mathrm{K}-12$ and higher education are also exploring active learning approaches to engage students in the learning process. Active learning, which focuses on the process of learning rather than on the content of the material, has been around for decades. Active learning is based on constructivist learning theory, which emphasizes learning new information through the integration of existing ideas, experiences, and knowledge. ${ }^{1}$ Students are encouraged to collaborate with other students and to be more actively engaged in the learning process. In the early twentieth century, John Dewey was one of the first to consider the use of active learning pedagogy in science education. Dewey thought science education should focus on problem solving and scientific inquiry rather than on rote memorization of facts and figures. ${ }^{2}$ In the 1960s, Joseph Schwab further developed the concept by advocating that students studying science take on the role of the scientist through experimentation, problem solving, and data analysis. ${ }^{3}$

Two methods of active learning pedagogy-inquiry-based and problem-based learning-were developed in the 1960s and 1970s. The inquiry-based learning method focuses on students' learning by asking questions and using primary sources to examine different points of view. Problem-based learning involves solving problems through investigation and using primary sources as evidence. ${ }^{4}$ In the last few decades, educational reformers promoted inquiry-based and problem-based learning for all levels of education and subjects, including history and science, and emphasized the need for students to develop critical thinking and information literacy skills to better utilize available information resources in the digital information age. ${ }^{5}$

In 1987, the Bradley Commission was established to examine the teaching of history in $\mathrm{K}-12$ education, which was in a state of decline. One of its recommendations was to teach using primary sources to help students develop critical analysis of historical events, rather than the recitations of facts, which had been the basis of prior history education. ${ }^{6}$ In the 1990s, educational reformers promoted using inquiry-based learning pedagogies and literacy skills to develop critical thinking skills. By 1996, the National Standards for 
History advocated for teaching historical research skills, including the historical analysis of primary sources, to promote critical thinking skills. ${ }^{7}$ The movement culminated in the 2009-2010 passing of the National Core Standards for history and English language arts, which include teaching literacy skills using primary sources beginning in elementary school. ${ }^{8}$

In the 1990s, higher education similarly adopted active learning pedagogies to engage students in the learning process. In 1998, the Boyer Commission sponsored by the Andrew Carnegie Foundation investigated undergraduate education in research universities. Its report, entitled "Reinventing Undergraduate Education: A Blueprint for America's Research Universities," concluded that undergraduate students, starting in their first year, should be engaged in historical research and introduced to inquiry-based learning to develop research and critical thinking skills. ${ }^{9}$

\section{Teaching with Primary Sources Trend in Archives}

The inquiry-based learning movement, and initiatives that recognize the importance of using primary sources to educate students at all levels, presents a great opportunity for archivists and special collections librarians. Not only do primary sources found in archives provide evidence of historical events, students learn critical thinking skills by analyzing primary sources and asking questions about what they say about history. The wider archives community has embraced these educational reforms. Individual archivists have developed digital collections and in-house consultation services for $\mathrm{K}-12$ teachers and higher education faculty, while professional organizations have worked to develop standards for information and primary source literacy. The traditional independent archival orientations have been reexamined for their impact in developing the critical thinking and research skills of undergraduate and graduate students, and archivists have become educators through co-teaching and teaching credited courses to students in a variety of subjects.

During the last two decades, archivists have developed digital collections and in-house consultation services for $\mathrm{K}-12$ teachers and higher education faculty. Digitizing collections to offer better access to materials for all patrons began in earnest in 1990s. Some archives, museums, and libraries have worked to develop curated digital collections especially designed for K-12 education, including prepared lesson plans and exercises. ${ }^{10}$ One of the leaders in creating digital collections designed for teaching with primary sources is the Library of Congress through its American Memory Project and Teaching with Primary Sources program. ${ }^{11}$ Similarly, college and university archives have developed faculty consultation programs in which faculty collaborate with archivists to identify primary source materials to use in their courses, or in some cases, archivists have even developed structured lesson plans for the faculty. For example, in 2007, Yale University opened the Collaborative Learning Center, which conducts course consultations. Its team of librarians and archivists collaborate with faculty to develop course objectives and assignments, and to identify appropriate collections, technology, and teaching methods. ${ }^{12}$ 
As a profession, librarians and archivists have also worked to develop standards for information and primary source literacy. In 2000, the Association of College and Research Libraries (ACRL) developed the "Framework for Information Literacy for Higher Education" to increase information literacy in undergraduate education. This framework, which was revised in 2016, provides six core concepts to help students understand how information is produced and valued, as well as how to use information to create new knowledge. These core concepts are 1) authority is constructed and contextual, 2) information creation is a process, 3) information has value, 4) research as inquiry, 5) scholarship as conversation, and 6) searching as strategic exploration. ${ }^{13}$ Similarly, in 2018, a joint task force of the Society of American Archivists (SAA) and the Rare Book and Manuscript Section (RBMS) of ACRL published "Guidelines for Primary Source Literacy" to educate librarians, archivists, teachers, and faculty on how to effectively use primary sources in their educational outreach and credited courses. ${ }^{14}$ Primary source literacy focuses on analyzing the attributes, characteristics, and provenance of primary sources to determine their authenticity, integrity, and accuracy. ${ }^{15}$ A related skill, "archival literacy," involves the knowledge needed to understand archival theory, practices, and research strategies to efficiently use primary source materials in archives. ${ }^{16}$

Traditionally, archivists have educated students on archival resources and research skills through independent archival orientation sessions. These sessions focus on introducing archival rules and procedures, identifying primary and secondary resources in the archives, and teaching historical research methods. Selected collections are traditionally displayed in a show-and-tell format to illustrate types of materials available. In some cases, students might engage in an active learning assignment such as examining documents and answering a series of questions designed to get them thinking critically about the collections. Several user studies have been conducted in the last two decades on the impact of these types of instruction. In their 2003 article, "Archival Intelligence and User Experience,” Elizabeth Yakel and Deborah Torres introduced criteria necessary for patrons to effectively use archival collections. These include domain or subject knowledge; artifactual literacy, or the ability to critically analyze and interpret documents; and archival intelligence, or the user's understanding of archival practices and principals, knowledge of research search strategies, and ability to identify primary and secondary sources. ${ }^{17}$ These components can be utilized in archival orientation sessions to improve students' ability to learn to be more critical and efficient users of archival materials. In 2008, Wendy Duff and Joan Cherry at Yale University studied the impact of archival orientation sessions. They found that students did gain a better understanding of archival research from these sessions, but that students indicated that they wanted more hands-on experience with primary source materials in the archives. ${ }^{18}$

In recent years, archivists have become more directly involved in education, taking an active role in teaching students to think critically through the use of historical research methods. In his 2001 article, “The Archivist as Educator," Marcus Robyns discussed archivists' role in the development of critical thinking skills through instruction in historical research methods, including analyzing the authenticity and provenance of documents as well as their content. Historians are trained to think critically and draw conclusions based 
on primary source evidence. Robyns advocated that archives can be educational laboratories for students doing similar historical research. ${ }^{19}$ In addition to teaching independent archival sessions, archivists co-teach or solo teach credited courses. Although history remains the most common subject, archivists are teaching credited courses in a variety of subjects including first-year seminars, science, and English. Archivists can play a role in credited courses by teaching sessions on historical research methods using selected resources from the archives. In a multiple-session approach, archivists can use active learning assignments such as discussions, essays, group activities, hands-on exercises, problem solving, role playing, presentations, and structured lesson plans to engage students with primary sources and instruct them in how to critically analyze sources for different points of view and to understand the difference between primary and secondary sources. ${ }^{20}$ In some cases, embedded archivists teach courses as the primary instructor. One recent example of the embedded archivist approach can be found at Shippensburg University in Pennsylvania, where, in a credited course on American environmental history, an archivist taught six workshops introducing research skills using primary source materials. Each workshop introduced a different step in the research progress: 1) introduction to archival research, 2) preparing a prospectus, 3) evaluating secondary sources, 4) evaluating primary sources, 5) revisiting the research prospectus, and 6) presenting and reflecting on the research. Each session included a lecture, a class discussion, and group assignments using selected archival materials to illustrate each step of the research process. ${ }^{21}$

\section{Teaching with Primary Sources in STEM classes}

This growing trend of archivists and educators using primary sources from the archives to educate students often focuses on history or other humanities classes. However, STEM (Science, Technology, Engineering, and Mathematics) classes have begun to embrace this trend as well. Although inquiry-based learning has been a mainstay in science education for decades, teachers and faculty initially met with some skepticism the idea that primary sources found in archives can be used to teach science. A 2008 survey conducted by the Society of American Archivists indicated that English and history were the subjects most requested for archival orientation sessions, while science was requested infrequently. ${ }^{22}$ However, archivists have successfully developed online digital resources for K-12 students, as well as curriculum-based courses that use primary sources, including undergraduate and graduate science courses such as mathematics, engineering, and geography. Some programs involve using primary sources to teach about current scientific discoveries. For example, in a program at the University of New Mexico, undergraduate mathematics students study well-known mathematicians and then examine how past discoveries affect current theories about solving math problems. ${ }^{23}$ Other courses use research methods to teach students critical thinking skills. Lindsay Anderberg from New York University's Tandon School of Engineering has written extensively on programs she and her colleagues have taught at her university. In a 2015 article, she wrote about a course for undergraduate engineering students that used the Keller Mechanical Engineering Corporation Collection to teach historical research methods and critical thinking skills. The students were provided with extensive training on historical research methods, including how to use archival resources such as finding aids to identify primary and secondary sources. This 
training was then applied to a research project using selected materials from the collection. Students came away with improved research and critical thinking skills, as well as a greater understanding of the engineering discipline. ${ }^{24}$

This study provides insight on how medical archives are embracing this trend of using primary sources in educational outreach. Medical archivists and special collections librarians conduct archival tours that include highlights from their archival collections to promote archival programs and services and to engage audiences in the history of medicine and science. History clubs and discussion groups utilize archival sources that students and club members can both study and use to present lectures on the history of medicine and the health sciences. Research competitions offer opportunities for students, faculty, and the public to conduct research in the medical archives and present their findings. Medical archivists and special collections librarians also co-teach or solo teach courses on a variety of subjects using rare books and archival materials from their collections.

\section{Survey Results: Educational Outreach in Medical Archives}

The author conducted a study using a 36-question survey and follow-up interviews to examine how the medical archives community is using primary sources in educational outreach. Questions were presented to participants depending on how they answered the survey. For example, question 4 asked participants to indicate the educational activities they offer at their archives. Depending on their responses, additional questions were asked about these activities. Similarly, question 5 asked participants to indicate what types of formal educational instruction their organization offers. Depending on their responses, more questions were asked about the specific types of instruction activities. The survey was sent to the listservs of the Archivists and Librarians in the History of Health Sciences (ALHHS) ${ }^{25}$ and the Society of American Archivists' Science, Technology, and Health Care Section. Forty-three out of 169 potential respondents completed the survey. Follow-up interviews were conducted with 4 people via telephone, and 6 people answered follow-up email questions providing more detailed information about their educational outreach activities. They were asked to provide specific examples of these activities, types of materials, and methods employed for using primary sources. Those who provided formal education activities were asked additional questions about the subject matters taught, number of classes taught per year, and relationships with faculty or K-12 teachers. All follow-up participants were asked about challenges with establishing these types of programs and whether doing educational outreach increased the visibility of the archives and reference services. Finally, in addition to the survey, the author also searched the websites of 71 medical archives across North America for evidence of educational outreach activities.

For the purpose of this study, a "medical archives" is defined as a repository whose mission is to collect and preserve the history of medicine in general or for a specific organization or agency. The 43 respondents came from a variety of medical archives, including colleges and universities (15), academic medical centers (14), nonprofit organizations (6), nonacademic hospitals/medical centers (2), and government agencies 
(1). Four of the survey respondents identified their parent organizations as "other," and one respondent failed to answer the question.

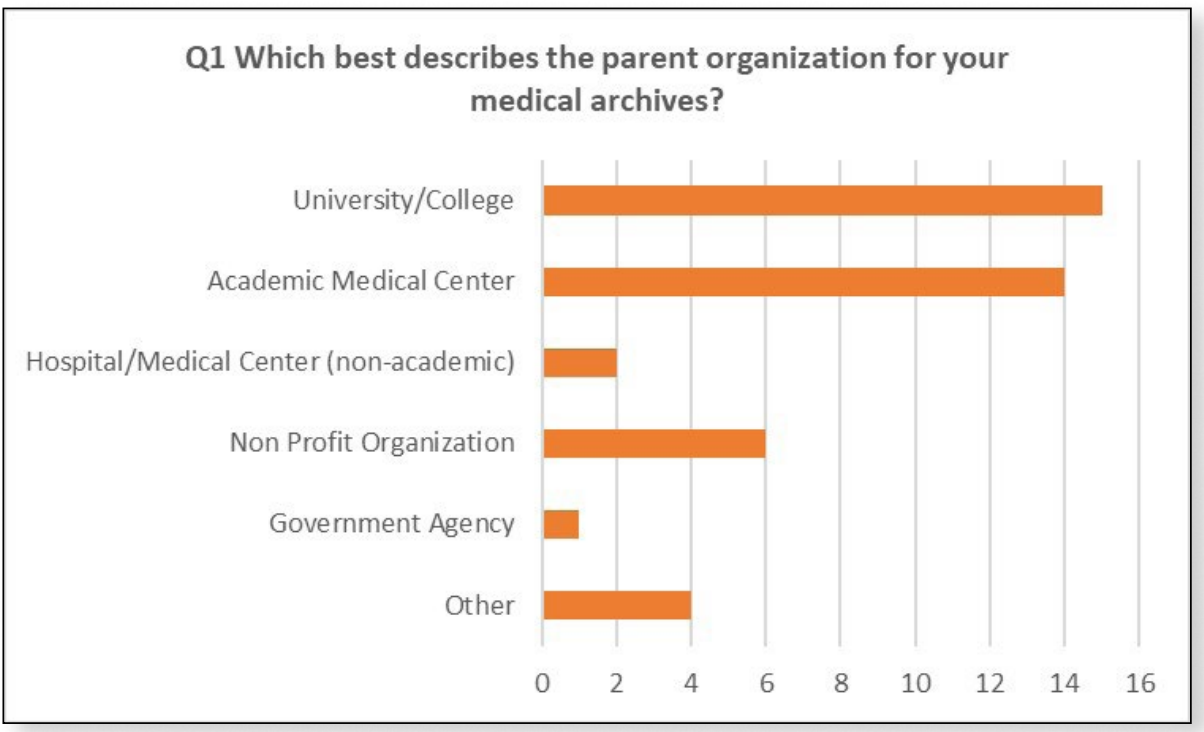

Figure 1: Type of organization (question 1)

The survey respondents identified their primary audiences as faculty, staff, and students (medical, undergraduate, and graduate) of their parent organizations; medical historians; and the general public.

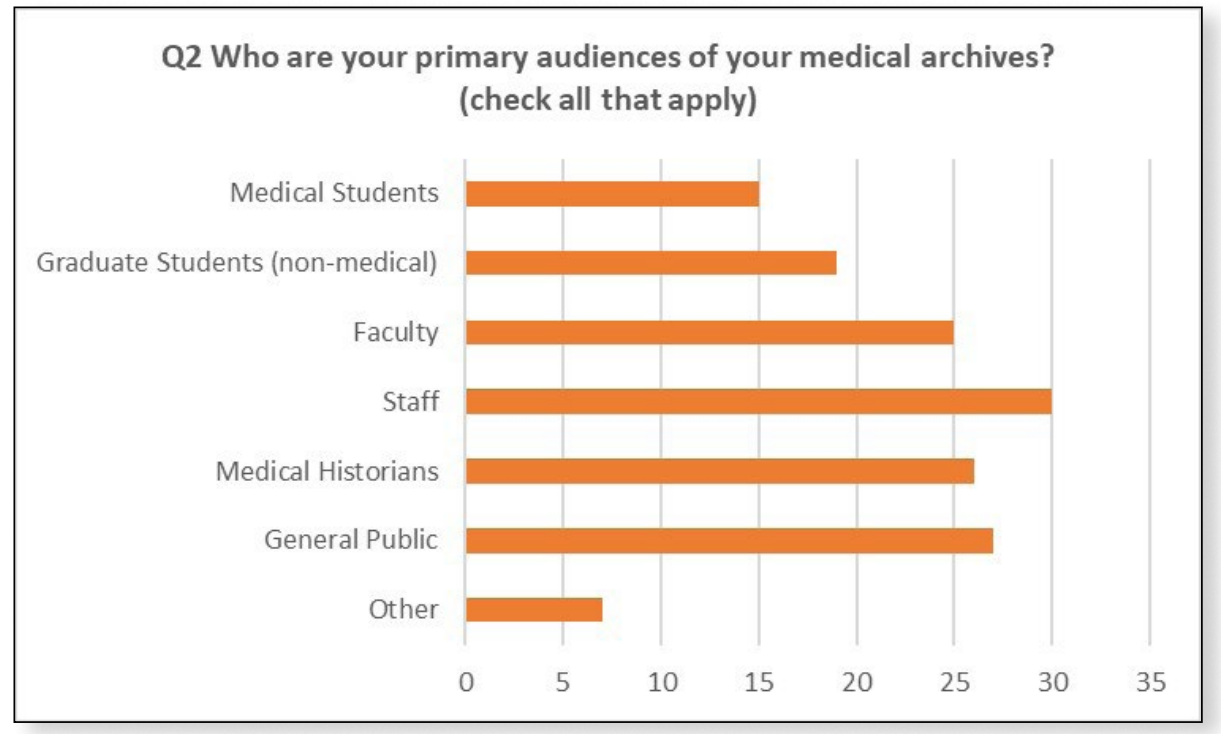

Figure 2: Primary audience (question 2) 
The majority of the medical archives stated that they collect a variety of material types including rare books, institutional archives, personal papers, audiovisual, and photographic materials.

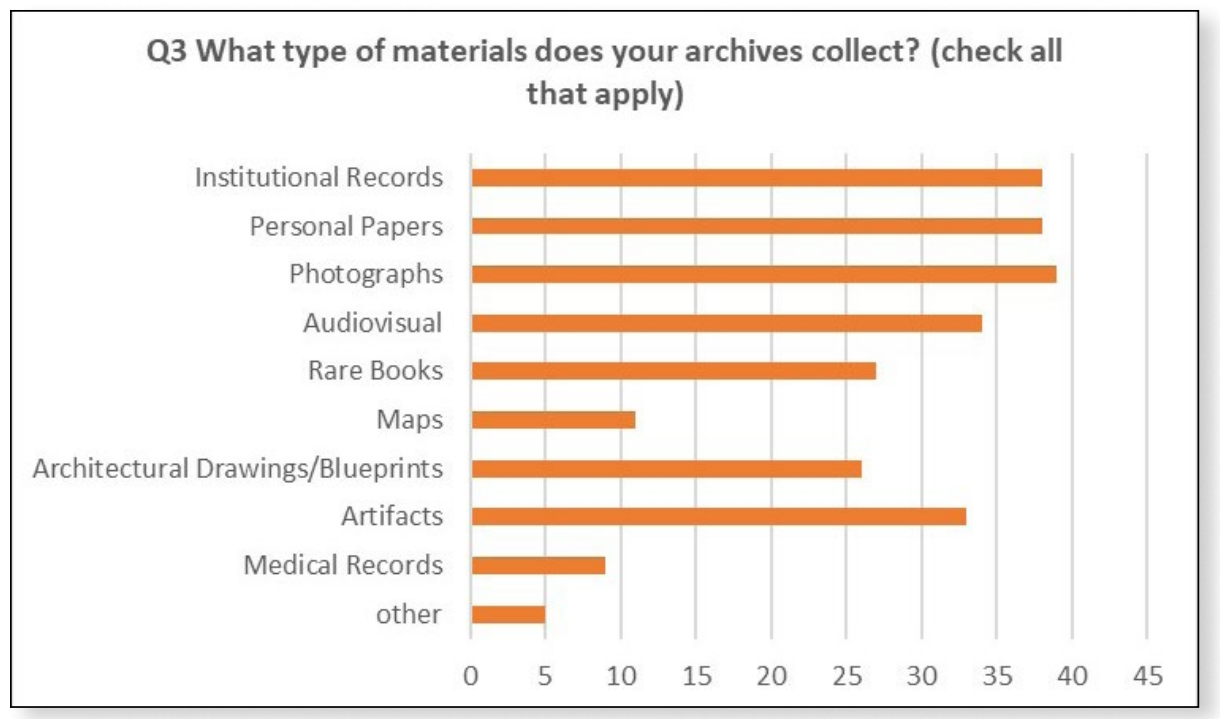

Figure 3: Types of materials collected (question 3)

The survey respondents also indicated that they engage in a variety of traditional outreach activities including in-house (39) and online (17) exhibits, archival tours (27), and lectures (18), while others facilitate history clubs (5), discussion groups (6), and/ or research competitions (5). Most notably, 22 (51\%) of the respondents are engaged in some type of formal educational instruction.

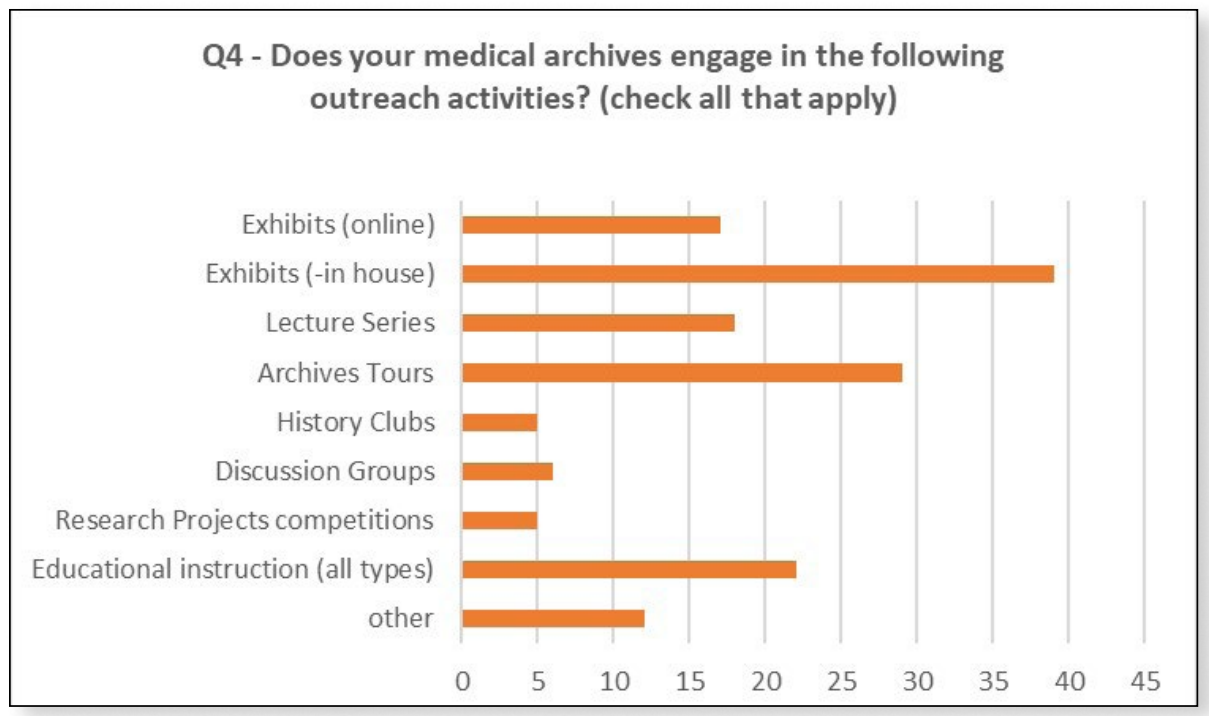

Figure 4: Outreach activities (question 4) 
Among those who engage in formal education instruction activities, the majority offer archival orientation sessions and independent studies, and several serve as co-teachers in faculty-led courses.

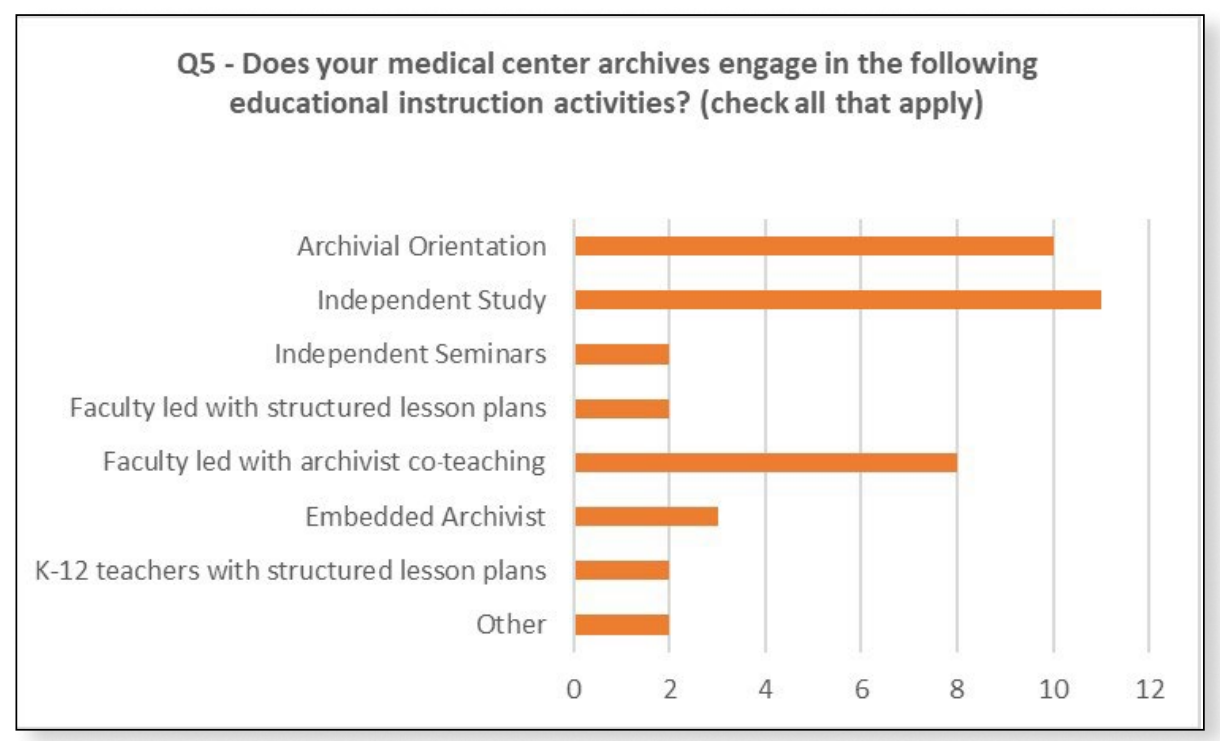

Figure 5: Types of educational instruction activities (question 5)

Finally, the survey respondents stated that the primary reasons for using primary sources in educational outreach activities are to engage their audiences (32), support the educational mission of their parent organization (18), and help their audiences develop critical thinking skills (6). The respondents could provide more than one answer to this question.

After reviewing the results of the study, the author made the following conclusions in regard to how medical archives are using primary sources in educational outreach activities:

\section{Medical archivists and special collections librarians are using primary sources in traditional educational outreach activities to both engage and educate audiences.}

Traditional educational outreach activities can be a good first step toward educating audiences about history and archival resources. Archivists and librarians are using primary sources to engage, promote, and entertain audiences. In some cases, these activities bring in audiences to conduct their own research, learn about history, and promote future scholarship. Mainstays like exhibits and lectures educate audiences on a variety of topics. Archival tours use primary sources to engage or entertain audiences with archival collections and to promote the archives' programs and services to VIPs or other targeted audiences. History clubs, discussion groups, and research competitions are ways to get members interested in history and to mentor new researchers in using 
archival collections. Employing primary sources in these activities makes history come alive for the audience.

In medical archives, one popular traditional method is providing archival tours that employ primary sources to educate and engage audiences. Survey respondents conduct tours for a variety of audiences, including the general public (15), staff (15), faculty (11), undergraduates (7), medical students (12), graduate students (9), and residents (5). Primary sources are traditionally displayed in a show-and-tell format, and the archivists/librarians use them to tell a story. A typical tour to educate the audience on the overall history of the organization and the type of records held by the repository might focus on collection highlights. Some tours focus on educating the audience on a specific subject such as medicine, science, literature, or art. For example, a tour on the history of medicine might include medical instruments, case books, and photographs to demonstrate how physicians treated patients in the past. Other tours promote or market the archives to VIPs within the organization or other targeted audiences. These tours are designed to get the audience interested in supporting the archives or using its resources. In some instances, tours are used to encourage the audience to become repeat users. One example of this type of tour is a monthly program at the New York Academy of Medicine Library. The popular noontime "First Monday" tours feature either a theme or selected highlights from the collections, including rare books, manuscripts, posters, pamphlets, ephemera, and photographs. The tours introduce people to the library's programs and collections, and, in some cases, encourage visitors to return as researchers. The tours are promoted using social media, postcards distributed in the building's lobby, and word-of-mouth. ${ }^{26}$ Washington University School of Medicine's Bernard Becker Medical Library has a similar First Friday tour, which features tabletop exhibits based on a theme. For example, one exhibit featured the school of nursing collections, displaying a mixture of materials such as documents on admission requirements, bulletins, and uniforms. The library marketing manager heavily promotes these tours as well as other outreach programs through social media, the library's website, posters distributed around campus, table tent displays on library tables, fliers, newsletters, and blogs. Some visitors return for other First Friday events. ${ }^{27}$ Other tours are purely for entertainment. For example, the New York Academy of Medicine Library partners with the organization Atlas Obscura to conduct theme-based tours three to five times per year. The tours are 1.5 hours long and based on a theme such as anatomy, natural science, astronomy, or women in medicine. Atlas Obscura takes care of the registration and marketing for the events. $^{28}$

Another way to use archival collections in outreach is to develop an annual event built around them. For example, Washington University School of Medicine's Bernard Becker Medical Library organizes an annual two-day event in December around its rare anatomical atlases that is open to the university and the public. The atlases are displayed on tables with talking points for each atlas to engage the audience with the materials. ${ }^{29}$ Other traditional outreach activities such as history clubs, discussion groups, and research competitions employ archival primary sources to encourage patrons to use archival resources. Thirteen medical archives reported having history or discussion 
groups, mostly for medical, graduate, and undergraduate students and faculty who are interested in the history of medicine. Some of these groups conduct research or discuss scholarly articles or books, while others invite speakers to discuss history of medicine topics. In some cases, archivists are invited to display selected materials pertaining to topics under discussion at the group meetings. In addition, members of these clubs conduct research for presentations to these groups. Five of the survey respondents hold research competitions, inviting medical, graduate, and undergraduate students; faculty; residents; and the general public to use the archives to conduct research that results in papers, essays, documentaries, posters, and websites. The competition organizers award prizes or scholarships to the participants. One such example is a research paper competition for medical students at Osler Library of the History of Medicine at McGill University in Montreal. Students submit their proposals to the library staff to review in the spring and are then matched with faculty advisors and conduct their research during the summer. In the fall, the library staff awards prizes to the participants. ${ }^{30}$ Similarly, the New York Academy of Medicine Library awards two residential fellowships each year to external researchers, most frequently doctoral students or early career faculty. The fellowships support research on the history of medicine at the academy and, in some cases, other archives in New York City. ${ }^{31}$

\section{Over half of the respondents reported using primary sources in formal educational outreach activities.}

Twenty-two (51\%) of the survey respondents reported engaging in formal educational outreach activities. Most use traditional teaching methods, including independent studies (13) and independent archival orientation sessions (10), while 8 support facultyled credited courses with archivists/librarians who guest teach one or more sessions. These formal educational efforts support the educational mission of the archives' parent organizations. None of the respondents reported having consultation services that work directly with faculty or $\mathrm{K}-12$ teachers to incorporate archival collections into their lesson plans. Medical archivists and special collections librarians should explore ways to become part of the wider archives trend to serve as educators in formal education settings.

\section{A. Medical archivists and special collections librarians are engaged in traditional forms offormal education.}

Some medical archivists/librarians are engaged in traditional formal education activities such as independent studies and independent archival orientation sessions. These sessions can be beneficial in supporting the educational mission of the archives. For example, orientation sessions can introduce students to historical research methods that can assist them in their own historical research projects or teach them critical thinking skills through analyzing collections and resources. Traditionally, these sessions use primary sources in the show-and-tell format. Archivists and librarians should utilize hands-on and group exercises to give students an opportunity to learn to be historians and to think critically about the materials. 
Independent studies can be a good way to introduce students to historical research methods. Eleven survey respondents reported offering independent studies for graduate (7), medical (5), and undergraduate (3) students. In these cases, the students undertake credited, independent studies to conduct research using the archives' materials. The archivists/librarians mentor the students, and the end product is generally a research paper. Two medical archives reported offering independent seminars for which the students meet as a group one or more times to get oriented to the archives and discuss or present their projects.

Archival orientations are the most widely used formal education method. The audiences include undergraduate, graduate, and medical students; faculty; residents; staff; and the general public. The most common format for using primary sources is show-and-tell, but, in some cases, students engage in hands-on or group exercises. Most sessions include familiarizing the audience with the resources available at the archives, explaining policies and procedures for using the materials, and, in some cases, providing guidance to participants who are conducting research for term papers. In sessions designed for students, archivists and librarians work closely with the faculty to select rare books and archival materials for the session. In some cases, the faculty also plan assignments connected to the sessions, such as research papers, blog essays, or hands-on or group exercises. For example, at Vanderbilt University School of Medicine's Jean and Alexander Heard Library, staff work with faculty to conduct sessions that provide an overview of the archival collections and resources to either support specific research assignments or to get the students interested in history. Archives staff select a variety of materials from the library's holdings, including rare books, archival materials, and surgical instruments. If faculty have assigned research projects, materials pertaining to them are selected. The archival and library staff teach the students how to find materials pertaining to their research projects in the archives and online, how to use rare books and archival materials, and why it might be important to use physical items as opposed to digital surrogates. ${ }^{32}$

\section{B. Some medical archivists and special collections librarians teach courses.}

Eleven medical archives noted that their staff are engaged in teaching credited courses. Eight respondents have staff who guest teach one or more sessions of a credited course with a faculty member, and three respondents have embedded archivists/librarians teaching credited courses. The archivists/librarians provide instruction about archival sources and then display archival materials for the students to examine. The courses that are being co-taught are for medical (3), STEM graduate (2), history graduate (2), history of medicine graduate (2), and history undergraduate students (2). Primary sources are being used in the show-and-tell format (6), hands-on exercises (5), research papers (3), and group projects and structured lesson plans (1).

Some archivists/librarians use primary sources to teach students to think critically about primary source materials. For example, at Osler Library of the History of Medicine at McGill University in Montreal, the head librarian works with both university faculty and secondary teachers to conduct archival sessions for students. Prior to the class, the students 
are provided with guidelines and pre-assessment questions (such as what is a manuscript? or what does "rare book" mean to you?) so they know what to expect when they visit the archives. One of many approaches the head librarian uses to encourage students to think critically about the materials is to have the students first examine the materials without any contextual information, and then they are given additional information. The head librarian then asks the students questions to get them to think critically about the materials. For example, a session on anatomy might include several anatomy books and documents that indicate how the study of anatomy has changed over time. ${ }^{33}$

\section{C. Medical archivists and special collections librarians are teaching courses or orientation sessions on a variety of subjects.}

Those medical archives that support formal education are using their collections to tell a variety of stories in their formal archival orientation sessions and curriculum-based courses, often in creative ways. Medical archives that offer independent archival orientation sessions teach students a variety of subjects, including science, history, history of medicine, and literature. For example, Washington University Medical School's Becker Medical Library regularly teaches German studies, women's studies, and art classes using items from the library's rare book collection. ${ }^{34}$ Medical archivists and special collections librarians co-teach courses in science, history of medicine, medical humanities, and library science. For example, staff at the Becker Medical Library co-teach three history of medicine courses each year, with six sessions in each course. During each class session, students spend an hour with their professor discussing assigned readings and an additional hour with archives staff studying rare books and archival materials that pertain to their assigned readings. The archives staff spend 30 minutes discussing the materials, and the students use the remaining time to review the materials and ask questions. One session is on the history of Washington University Medical School, which was formed when two medical schools merged with the university in 1890s. During this session, staff show archival materials illustrating the history of these predecessor schools, such as bulletins and photographs of the buildings, laboratories, classrooms, and classes. Students also view the original version of the school's Abraham Flexner report, which was not as positive as the one published in the official landmark report on medical education. ${ }^{35}$ The staff also show materials documenting other health-related programs, such as nursing, dentistry, and physical therapy. For example, students view nineteenth-century nursing student applicants' letters of support written by pastors and rabbis, which were required for acceptance to the Jewish Hospital Nursing School (now affiliated with the university). ${ }^{36}$

Medical archivists and special collections librarians at nonprofit organizations also engage in formal educational activities. At the New York Academy of Medicine Library, staff collaborate with faculty from several educational institutions in the New York metropolitan area to select materials and develop learning objectives, while faculty plan the actual assignments. Library staff conduct classes on a variety of subjects, including art, science, literature, and medicine. For example, the New York Academy of Medicine Library staff work with the faculty at Furman University in North Carolina to teach art students using a pedagogical model used to teach medical students how to observe by using visual materials. ${ }^{37}$ 


\section{D. The survey respondents did not report having faculty consultation services.}

None of the respondents reported providing education consultation services for faculty members wishing to use primary resources. However, some archives have had success building relationships with long-time faculty members who have been bringing their classes to the archives for independent sessions for many years. Faculty support is essential for building a formal education outreach program. Faculty and archivists/ librarians make good collaborators because faculty are the subject experts and archivists/ librarians are the archival literacy experts. Helping faculty utilize archival resources for their own lectures might lead to collaboration with faculty in co-teaching courses in the future. Archivists/librarians might pick one or two faculty to start with and build the program through these positive collaborations. ${ }^{38}$ There are many ways to build these relationships, such as attending organization events and faculty meetings, and using these opportunities to talk about the archives and the collections. Faculty learn about the archives by attending archives' educational programs such as exhibits, lectures, or tours. These events in turn get the faculty excited about history and archival collections, and they might become interested in either bringing classes to the archives or co-teaching with the archival/librarian staff. In addition, faculty learn about the archives' formal educational programs by word-of-mouth. One faculty member who has had a positive experience with an independent session or co-teaching a class will tell other faculty about the experience. ${ }^{39}$ Faculty interested in using the archives will benefit from working with the archivists/librarians to develop lesson plans and objectives of the course. Some faculty prefer to make the collection selection and the active learning assignments. In other cases, the archivists/librarians will make the collection selections and lead the assignments. Often, the approach is collaborative, with archivists/librarians selecting the materials based on faculty assignments or curriculum. ${ }^{40}$

\section{$2 E$. The survey respondents did not report supporting $K-12$ education.}

One missed opportunity is that medical archives may not be supporting the national core standards initiatives by providing digital or in-house services for $\mathrm{K}-12$ teachers and students. Only two medical archives reported doing programs for $\mathrm{K}-12$ students or teachers. These programs primarily consist of archival orientation sessions. For example, the head librarian at the Osler Library of the History of Medicine at McGill University in Montreal conducts course sessions for pre-university students (in Quebec, CEGEP students would be comparable to either high school seniors or first-year college students in the United States). In one of the sessions offered, the students choose a rare book, document, or image; conduct research on it using archival resources; and then create a blog post about their item. ${ }^{41}$

Although many archives make digital collections available online, none of the respondents reported designing such digital collections specifically for $\mathrm{K}-12$ or higher education students. Although these types of initiatives can be time consuming, they are a great way to get students, teachers, and faculty to use medical archives collections. One pioneer in providing digital sources for $\mathrm{K}-12$ education that did not respond to the survey is Drexel University's College of Medicine. Its online educational portal, Doctor 
or Doctress?, ${ }^{42}$ is specifically designed for students to create their own assignments rather than providing resources for teachers, and it allows students to explore various stories and themes using documents and accompanying questions. In addition, students have access to videos, digital scans of original documents, and transcripts that they can use to learn about a topic. ${ }^{43}$

\section{Many barriers prevent medical archives from becoming more involved in formal educational outreach activities.}

There are many challenges to providing formal educational outreach programs to students. One is working with faculty or administrators to include the archives in core curriculum or individual courses. Many archives also lack the administrative, financial, or human resources necessary to engage in robust outreach programs, while other archives lack visibility in terms of making their educators aware of the collections and resources. Finally, medical archives must take steps to protect information found in archival documents for the sake of patient privacy.

\section{A. Medical archivists and special collections librarians face challenges working with faculty or administrators to get the archives included in the curriculum of their parent organizations.}

Some medical archivists and special collections librarians reported facing challenges working with administration to get the archives included in the curriculum of their parent organizations. This can be particularly true of medical schools. Medical schools' main goal is to educate future doctors or medical scientists, so they tend to focus on clinical training and medical research. The curriculum's strict timeline leaves little time for history of medicine or medical humanities programs. Other obstacles include a lack of faculty educated in the history of medicine or medical humanities, and lack of funding to support such programming. ${ }^{44}$ Faculty or administrators may not understand the benefit of including history in their courses and of specifically using primary sources from the archives to teach critical thinking skills important for diagnosing patients or analyzing research data.

History can play a role in educating future medical professionals. In their article "Making the Case for History in Medical Education," David Jones and his co-authors discuss the importance of history in understanding of how medicine has changed over time in the treatment of diseases, medical technology advances, health-care inequalities, healthcare systems, and medical ethics. They argue that history can help future physicians understand current and future trends. ${ }^{45}$ For example, a recent project at the Medical Center Archives of New York-Presbyterian/Weill Cornell Medicine was to digitize nineteenth-century and early twentieth-century casebooks. These casebooks can provide historical data for researchers studying how treatment of diseases has changed over time. The New York Academy of Medicine Library offers its course on the "Pulse of Art" to medical students at Icahn School of Medicine at Mount Sinai. In it, books featuring collaborations between physicians and illustrators educate medical students on the value of these collaborations in promoting the careful observations needed to 
be good healers. ${ }^{46}$ Archivists and librarians who can think creatively about how their collections could be used in a variety of subjects will have more opportunities to become involved with the educational mission of their organizations. Medical archives that are successfully conducting formal education programs are mostly at institutions that include undergraduate and graduate degrees. These archives can use their collections to teach a variety of subjects, including science, art, English, and history of medicine.

\section{B. Some medical archivists and special collections librarians reported lack of time to invest in educational outreach.}

Another common challenge is the lack of time for archivists/librarians, especially in small shops, to invest in formal educational outreach. Archivists/librarians in small shops often must prioritize their projects and activities, and the basic work of cataloging and reference often takes priority over educational outreach. There is no doubt that developing courses can be a time-consuming task; however, building some key programs that can be used repeatedly might be possible. Archivists/librarians could start by developing some standard lectures about archival services and resources that can be used in all the archival orientation sessions. They could then identify key collections that can be used to develop some interesting hands-on or group exercises for multiple sessions. Some medical archivists and special collections librarians reported that they would like to hire outreach archivists/librarians who could develop these types of programs.

\section{C. Medical archives lack visibility.}

Some medical archives lack visibility within their parent organizations. In some cases, even the internal audience is not aware of the archives. This is particularly true of archives in isolated places such as basements or on top floors, away from where targeted audiences normally congregate. Traditional forms of outreach such as exhibits, tours, and lectures can help the archives become more visible to the wider community. Some archivists/librarians surveyed indicated that educational outreach activities may not always increase reference service, but they do increase the visibility of the archives.

\section{D. Medical archivists/librarians must protect the privacy of patient information.}

While the archivists/librarians interviewed for this study reported using only materials not protected by HIPAA (Health Insurance Portability and Accountability Act), such as rare books, annual reports, catalogs, and photographs of buildings and students, medical archivists/librarians must be aware of both HIPAA and state privacy laws when selecting materials for educational outreach. Patient records and other documents such as correspondence, administrative records, and photographs may contain protected health information (PHI). These records could potentially be rich sources for educating audiences about the history of medicine. For example, patient case studies can trace the history of diseases and treatments, surgical procedures, and medical recordkeeping practices, which can benefit the education of future medical students, health professionals, scientists, and historians. However, HIPAA protects the health information of American patients for 50 years after their death. Protected health information consists of 18 identifiers, including names, dates, medical record numbers, and full-face 
photographs. ${ }^{47}$ This information cannot be disclosed to others without the patient's or a representative's permission. An organization that holds records that contain this information must be a covered entity, which includes health insurance organizations, health-care clearinghouses, and health providers. ${ }^{48}$ Medical archives affiliated with academic medical centers, hospitals, or universities that provide health care are considered covered entities. Although HIPAA privacy rules govern records in most instances, more restrictive state laws may also apply. ${ }^{49}$ Archivists/librarians should familiarize themselves with both HIPAA and their state privacy laws to determine how they might affect any proposed use of records containing protected health information.

One challenge for archivists/librarians is determining whether HIPAA still applies to specific records because the death dates of the patients are often difficult to determine. In the case of older records no longer covered by HIPAA, the laws of individual states and local institutional policies may require an archives to protect the privacy of patients by not disclosing protected health information. Furthermore, no clear standards exist within the medical archives community for making these determinations and providing access to these materials. Individual repositories must find solutions within the scope of their HIPAA policies and work with the legal team at their institutions. One general solution might be to use copies that have been redacted of any PHI. The audience does not need to know the names, dates, or other personally identifiable information to learn from these patient records. Because specific information about medical treatment and diagnosis is not considered PHI, a redacted document can still provide rich information that could benefit an audience in an educational setting. Similarly, a photograph that contains patients could be still be used if the patients' faces are blurred. Researchers could still access the rich history found in these records without violating the privacy of the patients. However, redaction can be labor intensive for large projects such as online digitization projects and may not be worth the time and resources especially in smaller organizations. Archivists/librarians will have to work with their institutions' legal counsel to determine whether and how they can use these rich materials.

\section{Conclusion}

Over the last two decades, the wider archival community has responded to educational reforms in K-12 and higher education to employ inquiry-based learning pedagogy to both educate students and to promote the development of critical thinking skills using primary sources found in the archives. Archival orientation sessions, independent studies, and credited courses cotaught by archivists/librarians have been developed for students studying a variety of topics including history, science, literature, and art. At the same time, archivists/librarians are employing traditional educational outreach activities such as exhibits, archival tours, and clubs to engage audiences using primary sources in creative ways. While this study indicates that medical archivists and special collections librarians are engaging in traditional educational outreach activities such as exhibits, lectures, archival tours, and clubs to both educate and engage a variety of audiences, these activities most often employ primary sources using the show-and-tell format to create a story narrative for the audience. Such activities are a great first step 
in using primary sources to engage audiences with the history of medicine, to promote archival programs and services to VIPs and others, and to entertain audiences. Some medical archivists/librarians engage in formal educational outreach. Many academic medical archives conduct archival orientation sessions for a variety of subjects including science, art, literature, history, and history of medicine. Only a few of the survey respondents reported engaging in co-teaching of credited courses and embedding the archival collections more fully into the curriculum and individual courses of their parent organizations. Many obstacles, such as lack of faculty and administrative support for including an archives in the curriculum or educational mission of the organization, lack of financial and human resources to develop educational initiatives including digital collections, and a lack of visibility of an archives to its targeted audiences, bar medical archivists from these educational opportunities. Despite these hurdles, medical archivists and special collections librarians need to think more creatively about how their collections can be used to educate audiences and other ways in which they can participate more fully in this important educational opportunity.

\section{Appendix: Survey Questions ${ }^{50}$}

Q1 Which best describes the parent organization for your medical archives?

Q2 Who are your primary audiences of your medical archives? (check all that apply)

Q3 What type of materials does your archives collect? (check all that apply)

Q4 Does your medical archives engage in the following outreach activities? (check all that apply)

\section{Respondents were directed to the following questions depending on the type of outreach activities they selected in Q4:}

\section{Lecture Series}

Q14 Who are the primary audiences for your lecture series? (check all that apply)

Q15 What is the primary subject matter for the lecture series? (check all that apply)

\section{Archival Tours}

Q16 Who are the primary audiences of your archival tours? (check all that apply)

Q19 How do you use primary sources from your medical archives in your archival tours? (check all that apply) 


\section{History Clubs}

Q20 Who are the primary audiences of your history club? (check all that apply)

Q21 How do you use primary sources in your history club? (check all that apply)

Q23 Please describe your history club purpose and main activities?

\section{Discussion Groups}

Q22 Who are the primary audiences for your discussion groups? (check all that apply)

Q24 How do you use primary sources in your discussion groups? (check all that apply)

Q25 Please describe the purpose and main activities of your discussion group.

\section{Research Competitions}

Q26 Who are the primary audiences for your research projects competitions? (check all that apply)

Q27 What are the end products for the research competitions? (check all that apply)

Q5 Does your medical archives engage in the following educational instruction activities? (check all that apply)

Respondents were directed to the following questions depending on the type of educational instruction activities they selected in Q5:

\section{Archival Orientation Sessions}

Q6 Who are the primary audiences of your archival orientation sessions? (check all that apply)

Q35 How do you use primary sources in your archival orientation sessions? (check all that apply)

\section{Independent Studies}

Q31 Who are the primary audiences of your independent study? (check all that apply) 


\section{Independent Seminars}

Q32 Who are the primary audiences of your independent seminars? (check all that apply)

Q36 How do you use primary sources in your independent seminars? (check all that apply)

\section{Faculty Led Sessions with Structured Lesson Plans}

Q38 What are the subjects of the credited courses taught by faculty using a structured lesson plan developed by the archives?

(check all that apply)

Q39 How are primary sources used in courses taught by faculty using structured lesson plans developed by the archives?

(check all that apply)

\section{Faculty Led Credited Courses with Archivists Co-Teaching}

Q28 What are the subjects of the credited courses that the archivist guest lectures?

(check all that apply)

Q34 How are primary sources from your medical archives used in credited courses that the archivist guest lectures?

(check all that apply)

\section{Embedded Archivists}

Q29 What are the subjects of the credited courses taught by the embedded archivist?

(check all that apply)

Q37 How are primary sources from medical archives used in the credited courses taught by the embedded archivist?

(check all that apply)

Q30 What is the purpose in using primary sources in your educational outreach activities? (check all that apply)

Q8 Do you have a consultant program for assisting faculty/teachers in selecting archival materials for their courses?

Q9 Do you have curated online content from the medical archives for the purpose of formal education

(all levels)? 


\section{These questions were only asked if the participant answered yes in Q9:}

Q10 Who are the primary audiences of the curated online content for formal education? (check all that apply)

Q11 Does the online curated content include prepared lesson plans including exercises?

Q33 Anything else you would like to share about your educational outreach activities?

Q12 Are you willing to be contacted to discuss your educational outreach programs in more detail?

Q13 Please provide your contact information.

\section{ABOUT THE AUTHOR}

Elizabeth Shepard is the former associate archivist at the Medical Center Archives of New York-Presbyterian/Weill Cornell Medicine, where she was employed for over 18 years. Prior to this position, she worked for a variety of museums, libraries, and archives including George Eastman House (Rochester, NY), Chapman Museum (Glens Falls, NY), and the Montclair Public Library (NJ). She is currently employed as the archivist at the Bergen County (NJ) Division of Cultural and Historic Affairs. Shepard has an MA in museum studies from George Washington University and an MLS from SUNY Albany.

\section{NOTES}

1. Elizabeth Yakel and Doris Malkmus, "Contextualizing Archival Literacy," in Teaching with Primary Sources, ed. Chris Prom and Lisa Janicke Hinchliffe (Chicago: Society of American Archivists, 2016), 35.

2. Eun Al Lee and Matthew Brown, "Connecting Inquiry and Values in Science Education: An Approach Based on John Dewey's Perspective," PhiSci Archive, http://philsci-archive.pitt .edu/12563/1/Dewey_Value_Inquiry_090516.pdf.

3. Wikipedia, s.v. "Inquiry-based learning," https://en.wikipedia.org/wiki/Inquiry-based_learning.

4. Yakel and Malkmus, "Contextualizing Archival Literacy," 35.

5. Marcus Robyns, "The Archivist as Educator: Integrating Critical Thinking Skills in Historical Research Methods Instruction," American Archivist 64, no. 2 (2001): 366, https://doi.org/10.17723/ aarc.64.2.q4742x2324j10457.

6. National Council for History Education, "Bradley Commission Report: NCHE's Foundational Document," https://www.nche.net/bradleyreport.

7. Yakel and Malkmus, "Contextualizing Archival Literacy," 59; UCLA History, Public History Initiatives: National Center for History in the Schools, "National Standards for History, 1996," https://phi.history.ucla.edu/nchs/history-standards.

8. Common Core State Standards Initiative, "English Language Arts Standards: History/Social Studies," http://www.corestandards.org/ELA-Literacy/RH/introduction.

9. Boyer Commission on Educating Undergraduates at Research University, "Reinventing Undergraduate Education: A Blueprint for America's Research Universities," 1998, https://files.eric.ed.gov/ fulltext/ED424840.pdf. 
10. Several educational centers, cultural institutions, and universities are developing programs for both teachers and students who want to use primary sources in teaching. For examples, visit the following websites: We Are Teachers, "Best Educational Social Studies Websites," https://www .weareteachers.com/social-studies-websites; Gilder Lehrman Institute of American History, https:// www.gilderlehrman.org; National Archives, "Educational Resources," https://www.archives.gov/ education; Smithsonian National Museum of American History, "Engaging Students with Primary Sources," 2013, https://historyexplorer.si.edu/sites/default/files/PrimarySources.pdf.

11. Library of Congress, "Teaching with Primary Sources," http://www.loc.gov/teachers/tps.

12. Barbara Rockenbach, "Archives, Undergraduates, and Inquiry-Based Learning: Case Studies from Yale University Library,” American Archivist 74, no. 1 (2011): 301, https://doi.org/10.17723/ aarc.74.1.mml4871x2365j265.

13. Association of American College and Research Libraries, "Framework for Information Literacy for Higher Education," 2016, http://www.ala.org/acrl/standards/ilframework.

14. Society of American Archivists and Association of American Colleges and Research Libraries, "Guidelines for Primary Source Literacy," Society of American Archivists, 2018, https://www2 .archivists.org/sites/all/files/GuidelinesForPrimarySourceLiteracy-June2018.pdf.

15. Yakel and Malkmus, "Contextualizing Archival Literacy," 10.

16. Ibid., 11.

17. Elizabeth Yakel and Deborah Torres, "Archival Intelligence and User Experience," American Archivist 66, no. 1 (2003): 52, https://doi.org/10.17723/aarc.66.1.q022h85pn51n5800.

18. Wendy M. Duff and Joan M. Cherry, "Archival Orientation for Undergraduate Students: An Exploratory Study of Impact," American Archivist 71, no. 2 (2008): 520-21.

19. Robyns, "The Archivist as Educator," 368-74.

20. Sammie Morris, Tamar Chute, and Ellen Swain, "Teaching with Archives: Guide for Archivists, Librarians and Educators," in Teaching with Primary Sources, 96-109.

21. Christy Fic, "Working as an Embedded Archivist in an Undergraduate Course: Transforming Students into Scholars through an Archival Workshop Series," American Archivist 81, no. 2 (2018): 290-309, https://doi.org/10.17723/0360-9081-81.2.290.

22. Lindsay Anderberg, "STEM Undergraduates and Archival Instruction: A Case Study at NYU Polytechnic School of Engineering," American Archivist 78, no. 2 (2015): 550, https://doi .org/10.17723/0360-9081.78.2.548.

23. Janet Barnett et al., "Using Primary Sources Projects to Teach Mathematics," AMS Blogs, January 20, 2015, American Mathematical Society, https://blogs.ams.org/matheducation/2015/01/20/ using-primary-source-projects-to-teach-mathematics.

24. Anderberg, "STEM Undergraduates and Archival Instruction," 555-62.

25. In April 2020, the organization rebranded itself as Librarians, Archivists and Museum Professionals in the History of the Health Sciences (LAMPHHS).

26. Arlene Shaner, telephone interview by the author, June 10, 2019, and email message to the author, April 26, 2020.

27. Stephen Logsdon, telephone interview by the author, June 10,2019, and email message to the author April 28, 2020.

28. Shaner, interview, June 10, 2019.

29. Logsdon, interview, June 10, 2019.

30. Mary Yearl, telephone interview by the author, 2019.

31. Shaner, email, April 28, 2020.

32. Christopher Ryland, telephone interview by the author, June 10, 2019, and email message to the author, April 27, 2020

33. Yearl, interview, 2019.

34. Logsdon, interview, June 10, 2019, and email, April 28, 2020. 
35. Abraham Flexner was an educational reformer commissioned by the Carnegie Foundation to study the state of medical education in the United States and Canada. Flexner visited 155 medical schools and published his landmark report, "Medical Education in United States and Canada," in 1910. Flexner's critique of the medical schools led to educational reforms and, in some cases, the closing of medical schools. The Rockefeller Archive Center, "People: Abraham Flexner," The Rockefeller Foundation: A Digital History, https://rockfound.rockarch.org/biographical/-/asset_publisher/6ygcKECNI1nb/content/abraham-flexner.

36. Logsdon, interview, June 10, 2019, and email, April 28, 2020.

37. Shaner, interview, June 10, 2019.

38. Morris, Chute, and Swain, "Teaching with Archives," 87.

39. Shaner, Ryerson, Logsdon, email messages.

40. Ibid.

41. Yearl, interview, 2019.

42. Drexel University, "Doctor or Doctress? Explore American History through the Eyes of Women Physicians," May 2014, http://doctordoctress.org.

43. Morris, Chute, and Swain, "Teaching with Archives," 173.

44. David Jones, Jeremy Greene, Jacalyn Duffin, and John Harley Warner, "Making the Case for History in Medical Education," Journal of the History of Medicine (2014): 12.

45. Ibid., 4-19.

46. Shaner, interview, June 10, 2019.

47. In HIPAA, PHI is defined by 18 identifiers that include names, dates except year, telephone numbers, geographic data, fax numbers, Social Security numbers, email addresses, medical record numbers, account numbers, health plan beneficiary numbers, certificate/license numbers, vehicle identifiers, web URLS, device identifiers and serial numbers, internet protocol addresses, full-face photographs, biometric identifiers, and unique numbers or codes, HIPAA Journal, "What Is Considered PHI under HIPAA?," https://www.hipaajournal.com/considered-phi-hipaa.

48. US Department of Health and Human Services, National Institutes of Health, "To Whom Does the Privacy Rule Apply and Whom Will It Affect?," last modified February 2, 2007, https://privacyruleandresearch.nih.gov/pr_06.asp.

49. US Department of Health and Human Services, "Preemption of State Law," https://www.hhs.gov/hipaa/for-professionals/faq/preemption-of-state-law/index.html.

50. Questions 7, 17, and 18 were eliminated in the course of designing the survey. 